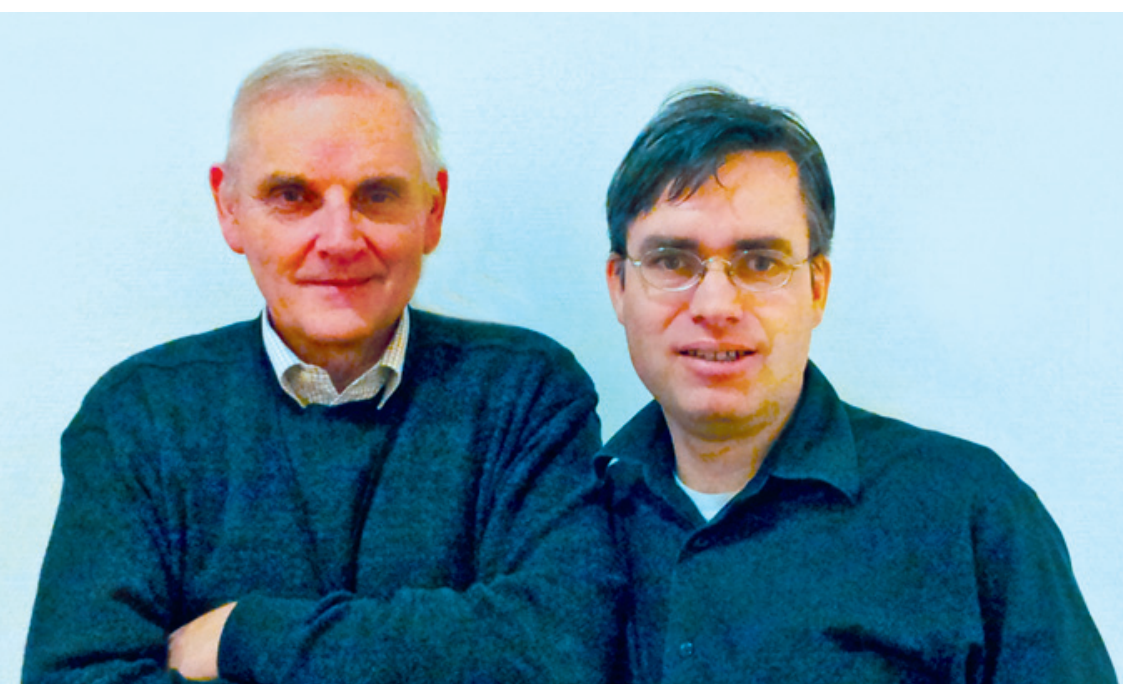

Steinar Tretli (til venstre) og Harald Weedon-Fekjær. Foto privat

\section{Forekomst av brystkreft påvirkes av mammografi og hormoner}

Svingninger i insidensen av brystkreft kan forklares av mammografiscreening og variasjoner i hormonbruk rundt overgangsalderen.

Det viser ny norsk studie.

Kreftregisteret startet registrering av alle norske brystkrefttilfeller i 1952. Frem til midten av 1990-årene var det en jevn økning i brystkreftinsidensen. Fra midten av 1990-årene økte insidensen sterkt, for deretter å flate ut tidlig i på 2000-tallet, og fra rundt 2006 har det vært et svakt fall i hyppigheten av brystkreft i Norge. I flere andre land har det vært et tilsvarende fall i hyppighet de siste årene.

I tidligere studier har det vært pekt på at de store svingningene $\mathrm{i}$ insidens siden 1990-årene kan skyldes mammografiscreening og bruk av hormonbehandling. I den nye studien brukte forskerne norske registerdata og statistisk modellering for å skille de to faktorenes bidrag til insidensutviklingen (1).

- Resultatene viser at bruk av hormoner rundt overgangsalderen og innføringen av mammografiscreening kan forklare avvikene fra den gradvise økningen i brystkrefthyppighet fra 1950- til 1990-årene, og at begge faktorer trolig har bidratt betydelig, sier førsteforfatter Harald Weedon-Fekjær ved Kreftregisteret. Da brystkrefthyppigheten blant 50-69 år gamle norske kvinner var på sitt høyeste i 2002, anslår vi at $23 \%$ av tilfellene i denne aldersgruppen kan tilskrives mammografiscreening og $27 \%$ bruk av hormoner på grunn av plager rundt overgangsalderen.

Vi har ikke undersøkt om brystkreftøkningen knyttet til mammografiscreening skyldes overdiagnostikk eller bare tidligere diagnose. Det vil inngå i den kommende evalueringen fra Norges forskningsråd av det norske mammografiscreeningprogrammet, sier Weedon-Fekjær.

\section{Mammografiforskning}

Artikkelen er skrevet av Harald WeedonFekjær, Kjersti Bakken, Lars J. Vatten og Steinar Tretli. Weedon-Fekjær og Tretli er statistikere ved Kreftregisteret, mens Bakken og Vatten er henholdsvis farmasøyt og medisiner av bakgrunn, og arbeider ved universitetene i Tromsø og Trondheim. Prosjektet er finansiert av Kreftforeningen. Tidligere arbeider omfatter estimering av vekstraten til brystkreftsvulster ved bruk av norske mammografidata, som ble kåret til årets artikkel 2008 av Norsk forening for epidemiologi (2). Under arbeidet med modellering av progredieringsraten til kreftsvulster var det behov for kunnskap om insidenstrender, og det ble et utgangspunkt for studien som nå er publisert i $B M J$.

\section{Erlend Hem}

erlend.hem@medisin.uio.no

Tidsskriftet

\section{Litteratur}

1. Weedon-Fekjær H, Bakken K, Vatten LJ et al. Understanding recent trends in incidence of invasive breast cancer in Norway: age-period-cohort analysis based on registry data on mammography screening and hormone treatment use. BMJ 2012: 344: e299.

2. Weedon-Fekjær $H$, Lindqvist $B H$, Vatten LJ et al. Breast cancer tumor growth estimated through mammography screening data. Breast Cancer Res 2008; 10: R41.

Publisert først på nett 30.1. 2012.

\section{Ordforklaringer}

Poissonregresjon: Statistisk regresjonsanalyse utført på telledata, typisk risikoen for en gitt sykdom innen definerte kombinasjoner av mulige risikofaktorer

Alder-periode-kohort-analyser (Age-PeriodCohort, APC-analyser): Analyse av risikoen for en gitt begivenhet, typisk kreftsykdom, ved å dele materialet etter alder, kalendertid (periode) og fødselskohort, og studere sammenhengen mellom sykdomshyppighet og hver av faktorene ved bruk av poissonregresjon.

Tilskrivbar risiko: Risikoen som kan tilskrives en gitt variabel, ofte beregnet via statistisk regresjonsanalyse.

Hormonsubstitusjonsbehandling i klimakteriet: Hormoner mot plager i overgangsalderen ble stadig mer populært blant norske kvinner før studier viste en betydelig forhøyet risiko for brystkreft, og mindre positive helsegevinster enn tidligere antatt. Fra og med år 2002 har salget/bruken av hormoner mot plager rundt overgangsalderen falt kraftig

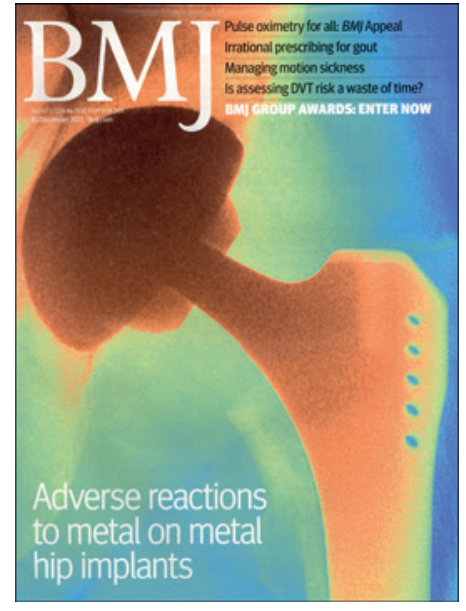

Artikkelen ble publisert 30.1. 2012 i BMJ (www.bmj.com), som regnes som en av de «fem store» innen medisinsk publisering, ved siden av New England Journal of Medicine, JAMA, Annals of Internal Medicine og The Lancet 